\title{
Chimera of Globin/Nitric Oxide Synthase: Toward Improving Nitric Oxide Homeostasis and Nitrogen Recycling and Availability
}

\author{
Fiorella Del Castello ${ }^{\dagger}$, Andrés Nejamkin ${ }^{\dagger}$, Noelia Foresi, Lorenzo Lamattina \\ and Natalia Correa-Aragunde*
}

Instituto de Investigaciones Biológicas, Consejo Nacional de Investigaciones Cientificas y Técnicas (CONICET), Universidad Nacional de Mar del Plata - CONICET, Mar del Plata, Argentina

Keywords: cyanobacteria, globin, nitric oxide synthase, nitrogen use efficiency, nitrogen recycling, plants

\section{OPEN ACCESS}

Edited by:

Susana Puntarulo,

University of Buenos Aires, Argentina

Reviewed by:

Andres A. Caro,

Hendrix College, United States

C.-Elisa Schaum,

University of Hamburg, Germany

*Correspondence:

Natalia Correa-Aragunde

mncorrea@mdp.edu.ar

${ }^{\dagger}$ These authors have contributed equally to this work

Specialty section:

This article was submitted to Marine and Freshwater Plants,

a section of the journal

Frontiers in Plant Science

Received: 24 June 2020 Accepted: 04 September 2020 Published: 30 September 2020

Citation:

Del Castello F, Nejamkin A, Foresi N, Lamattina $L$ and Correa-Aragunde $N$ (2020) Chimera of Globin/Nitric Oxide

Synthase: Toward Improving Nitric Oxide Homeostasis and Nitrogen Recycling and Availability.

Front. Plant Sci. 11:575651. doi: 10.3389/fp/s.2020.575651

\section{INTRODUCTION}

As a result of anthropogenic activities, there are regions suffering extreme climate changes (hot temperatures, droughts, floods), that generate serious and harmful environmental and socioeconomic consequences (Hoegh-Guldberg et al., 2018). Climate change has a strong impact on agriculture, mainly by increasing soil degradation and reducing land productivity (Olsson et al., 2019). Desertification decreases soil macronutrients as organic carbon (OC), phosphorus (P) and nitrogen (N) (Shang et al., 2013; Tang et al., 2015). Considerable reductions of OC, P and N are caused by a decline in soil water, vegetation and wind erosion. It is estimated that when soil water is less than 30\%, OC and $\mathrm{N}$ decrease approximately 50\% (Shang et al., 2013). The intensity and frequency of extreme climate events predicted will increase the competition for nutrients, notably $\mathrm{N}$ among plants and soil microorganisms (Bennett and Klironomos, 2019; Pugnaire et al., 2019).

$\mathrm{N}$ availability is essential for net primary production and determines changes in total vegetation biomass and soil OC (Tharammal et al., 2019). Approximately $150 \mathrm{Tg} / \mathrm{yr}$ of $\mathrm{N}$ is spilled to the land surface as a result of industrial activities and fossil fuel combustion (Schlesinger, 2009). Huge amounts of $\mathrm{N}$ fertilizers are used to increase crop productivity, but only $25 \%-30 \%$ are retained in plant biomass (Nadelhoffer et al., 1999; Schlesinger, 2009). The excess of $\mathrm{N}$ is then transported to aquatic environments resulting in eutrophication and reduction of dissolved $\mathrm{O}_{2}$, percolated to the groundwater or loss to the atmosphere, increasing greenhouse gas (GHG) emissions such as nitrogen oxides (NOx) (Schlesinger, 2009; Breitburg et al., 2018). In this context, bio/technological solutions like genetic modification of crops are required to avoid, reduce and reverse GHG emissions and water eutrophication, contributing to climate change mitigation. New biotechnological strategies developed for the agriculture to increase $\mathrm{N}$ use efficiency (NUE) in crops would help to fulfill this purpose. In this opinion, we will discuss some studies of nitric oxide (NO) synthases (NOS) and nitrate reductase (NR) enzymes playing a collaborative role with globin $(\mathrm{Hb})$ proteins, leading to NO and/or nitrate $\left(\mathrm{NO}_{3}{ }^{-}\right)$homeostasis in different organisms. We propose that chimeric globin-NOS such as the NOS from Synechococcus PCC 7335 (SyNOS) may have evolved in photosynthetic microorganisms contributing to a more efficient $\mathrm{N}$ recycling and sustaining growth in $\mathrm{N}$ fluctuating conditions. Engineered crops that maximize NUE would result in a better adaptation to changing climatic conditions with less $\mathrm{N}$ fertilization, preserving aquatic ecosystems and atmosphere. 


\section{NITRIC OXIDE/NITRATE HOMEOSTASIS BY THE ASSOCIATION OF NITRIC OXIDE SYNTHASE AND GLOBIN}

NOS enzymes catalyze the oxidation of Arginine (Arg) to produce citrulline and NO, a molecule that participates in diverse processes ranging from growth and development and stress responses (Alderton et al., 2001; Crane et al., 2010; Del Castello et al., 2019). Mammalian NOSs have a N-terminal oxygenase domain (NOSoxy) and a C-terminal reductase domain (NOSred) joined by a calmodulin binding motif (Griffith and Stuehr, 1995). In Gram positive bacteria, NOS have only one domain and consist of NOSoxy similar to that of animals (Crane et al., 2010). NOS proteins were also identified in photosynthetic microorganisms such as green algae, diatoms and cyanobacteria (Foresi et al., 2010; Di Dato et al., 2015; Kumar et al., 2015). While a NOS-like activity has been detected in plant extracts (Corpas and Barroso, 2017), the search in more than 1000 sequenced transcriptomes suggests that this gene is not present in terrestrial plants (Jeandroz et al., 2016; Foresi et al., 2017). This is intriguing, and raises the question of whether, in terrestrial plants, NOS has not been searched correctly, or simply is not present. Particularly, the characterization of a NOS in the cyanobacterium Synechococcus PCC 7335 (SyNOS) opens new and interesting questions regarding its biological function since it is a chimera of a globin domain joined to a canonical NOS (Correa-Aragunde et al., 2018).

Globins (Hbs) are heme-proteins comprising three families, flavohemoglobin (FHb), globin-coupled sensors and truncated-Hb (THb). The main function of Hbs is related to NO detoxification by a NO dioxygenase (NOD) activity oxidizing $\mathrm{NO}$ to $\mathrm{NO}_{3}^{-}$ (Vinogradov and Moens, 2008). The interaction of NO molecule and Hbs was studied in bacteria, animals and plants (Poole and Hughes, 2000; Seregélyes and Dudits, 2003; Tejero and Gladwin, 2014). However, the current knowledge shows that there are few examples of a coupled reaction between NOS enzymes and $\mathrm{Hb}$ and leading to $\mathrm{NO} / \mathrm{NO}_{3}{ }^{-}$release regulation. In mammals, endothelial NOS (eNOS) associates with $\alpha-\mathrm{Hb}$ to modulate NO diffusion during vascular smooth muscle relaxation. $\alpha-\mathrm{Hb}$ binds to eNOS and oxidates $\mathrm{NO}$ to $\mathrm{NO}_{3}^{-}$, preventing that $\mathrm{NO}$ reaches smooth muscle cells (Straub et al., 2012). The interaction between NOS and $\mathrm{Hbs}$ to regulate NO homeostasis has also been reported in bacteria. Staphylococcus aureus generates energy using $\mathrm{NO}_{3}{ }^{-}$as an alternative electron acceptor in $\mathrm{O}_{2}$ limiting conditions and it is principally regulated by NOS and HMP (bacterial FHb) (Kinkel et al., 2016). Under micro-aerobic conditions, NOS-derived NO inhibits aerobic respiration by interacting with cytochrome oxidases. Under aerobic conditions, NO consumption predominates by HMP activity providing a homeostatic mechanism that modulates respiration in response to $\mathrm{O}_{2}$ availability (Kinkel et al., 2016).

\section{HBS AND NO PARTICIPATION IN N METABOLISM IN PHOTOSYNTHETIC ORGANISMS}

More interestingly, the interaction of $\mathrm{Hbs}$ and $\mathrm{NO}$ has a remarkable role in the $\mathrm{N}$ metabolism of photosynthetic organisms. $\mathrm{N}$ metabolism was largely studied in higher plants, green algae and diatoms (Flynn, 1991; Coruzzi and Zhou, 2001; Bertoni, 2017). Once $\mathrm{NO}_{3}{ }^{-}$is internalized, it is reduced to $\mathrm{NO}_{2}{ }^{-}$by $\mathrm{NR}$, the first enzyme in the assimilation pathway (Wilkinson and Crawford, 1991). In Chlamydomonas, $\mathrm{NO}_{2}{ }^{-}$is the substrate of NOFNiR (NO Forming $\mathrm{NO}_{2}{ }^{-}$Reductase) that catalyzes $\mathrm{NO}$ production even in the presence of high (millimolar) concentrations of $\mathrm{NO}_{3}{ }^{-}$, which inhibits $\mathrm{NO}$ production by the $\mathrm{NO}_{2}{ }^{-}$reductase activity of NR. NOFNiR together with NR are intimately connected both at transcriptional and posttranscriptional regulatory levels suggesting enzyme cooperativity (Chamizo-Ampudia et al., 2016; Llamas et al., 2017). Furthermore, $\mathrm{NO}_{3}{ }^{-}$controls the expression of $\mathrm{THb}$ by regulating transcription factors activity. THB1 generates a direct connection between $\mathrm{NO}$ and $\mathrm{NO}_{3}{ }^{-}$metabolism by modulating $\mathrm{NO}$ levels and NR activity. NR is also able to reduce THB1, through its diaphorase activity. Interestingly this activity is more efficient than others reducing cofactors like $\mathrm{NADH}, \mathrm{FAD}$, or cytochrome b5 reductase which possesses high homology to NR (Sanz-Luque et al., 2015).

The interaction between NR and THB1 in N metabolism has also been demonstrated in diatoms. Smith et al. (2019) show that two of the strongest $\mathrm{NO}_{3}{ }^{-}$sensitive genes were part of the $\mathrm{Hb}$ superfamily with high homology to THB1 from Chlamydomonas. Considering these evidences, the interaction NR-THB1 seems to work as a complex for $\mathrm{NO}$ and $\mathrm{NO}_{3}{ }^{-}$homeostasis. Scavenging of $\mathrm{NO}$ to produce $\mathrm{NO}_{3}{ }^{-}$, maximizes $\mathrm{NR}$ efficiency during $\mathrm{N}$ assimilation diminishing $\mathrm{N}$ loss (as gaseous $\mathrm{NO}$ ), improving $\mathrm{N}$ utilization in photosynthetic organisms.

\section{CHIMERIC GLOBIN-NOS FROM SYNECHOCOCCUS PCC 7335 AND ITS POTENTIAL ROLE IN N METABOLISM}

The NOS from Synechococcus PCC 7335 (SyNOS) was the first NOS characterized that contains a globin domain (CorreaAragunde et al., 2018). Biochemical analysis showed that SyNOS produces $\mathrm{NO}$ and $\mathrm{NO}_{3}{ }^{-}$in vitro in an approximately $1: 3$ ratio and data suggest that the globin domain is mainly responsible for $\mathrm{NO}_{3}$ production (Picciano and Crane, 2019). Chimeric globin-NOS similar to SyNOS appears in some diatom and cyanobacteria genomes (Di Dato et al., 2015; Correa-Aragunde et al., 2018).

Heterologous expression of SyNOS in Escherichia coli allows bacteria to improve growth under limiting $\mathrm{N}$ conditions. Furthermore, SyNOS expression may contribute the use of Arg as a $\mathrm{N}$ source in bacteria (Correa-Aragunde et al., 2018). In cyanobacteria and plants, Arg serves as a major organic $\mathrm{N}$ storage and transport. Thus, Arg metabolism plays a key role in $\mathrm{N}$ distribution and remobilization in these organisms (Winter et al., 2015). Arg dihydrolase, another novel enzyme recently characterized, converts Arg to ornithine, $\mathrm{CO}_{2}$ and ammonium (Zhang et al., 2018; Burnat et al., 2019). Results indicate that Arg dihydrolase is part of a mechanism involved in $\mathrm{N}$ storage and remobilization in cyanobacteria conferring rapid adaptability to $\mathrm{N}$ fluctuations (Zhang et al., 2018). N fluctuation in aquatic environments, mainly rivers, lakes, estuaries and marine coastal regions, are result of precipitation events, droughts, wind velocity and warming affecting water-sediment interactions and 
anthropogenic $\mathrm{N}$ inputs (Conley et al., 2009; Havens et al., 2016). We predict that fluctuations in $\mathrm{N}$ availability will become more severe in a faster and unpredictable climate change.

The characterization of novel functional genes is significant for the understanding of the mechanisms governing the adaptation to changing environmental conditions. Chimeric genes provide an exceptional source of new cell functions, resulting in organisms that may adapt to different environments by developing new metabolic skills. The characterization of the chimera globin-NOS like SyNOS could break a paradigm on NOS biological functions. In our opinion, SyNOS represent a sophisticated evolution of NOS genes with the ability to regulate the $\mathrm{NO} / \mathrm{NO}_{3}{ }^{-}$homeostasis and signaling, besides the potential function in $\mathrm{N}$ metabolism.

\section{SYNOS EXPRESSION AS A BIOTECHNOLOGICAL STRATEGY TO IMPROVE NUE IN PLANTS}

Early attempts to increase NUE and yield in crops were based in manipulating $\mathrm{NO}_{3}{ }^{-}$transporters or $\mathrm{N}$ assimilation genes, but negative or contradictory results suggest that is a complex agronomic trait ( $\mathrm{Li}$ et al., 2017). NR overexpression affected intracellular $\mathrm{NO}_{3}{ }^{-}$levels but did not increase yield nor improve plant growth (Ferrario-Méry et al., 1998; Djennane et al., 2002). More promising results have been achieved by manipulating genes involved in plant $\mathrm{N}$ remobilization (Oliveira et al., 2002; Gaufichon et al., 2017; Chen et al., 2019). Specially, the manipulation of genes involved in amino acid catabolism and transport seems to be good strategies to remobilize organic $\mathrm{N}$ storage increasing seed filling and plant yield (Good et al., 2007; Shrawat et al., 2008; Ma et al., 2013; Meng et al., 2015; Perchlik and Tegeder, 2017).

In this opinion, we propose that the expression of the chimeric globin-NOS from Synechococcus PCC 7335 could improve cellular $\mathrm{N}$ metabolism enhancing NUE and crop production under $\mathrm{N}$ shortage conditions. There are already evidences of NOS from different origins (animals and algae), recombinantly expressed in plants (Rodríguez-Ruiz et al., 2019). In all cases, the NOSs expressed are active in the transgenic plants displaying high $\mathrm{NO}$ levels and stress tolerance (Chun et al., 2012; Shi et al., 2012; Shi et al., 2014; Cai et al., 2015; Foresi et al., 2015). SyNOS as well as animal NOS function with tetrahydrobiopterin $\left(\mathrm{BH}_{4}\right)$ cofactor and not with tetrahydrofolate (THF) (Picciano and Crane, 2019), the main known pterin in plants (Sahr et al., 2005). However, plants can enzymatically produce dihydrobiopterin $\left(\mathrm{BH}_{2}\right)$, and it was reported that the photosynthetic apparatus can reduce pterins from dihydro to tetrahydro form (Fuller and Nugent, 1969). Otherwise, it is known that other pterins can fulfill NOS activity (Presta et al., 1998). Recently, Nejamkin et al. (2020) have shown that the expression of the NOS from the algae Ostreococcus tauri (OtNOS) in tobacco increases growth rate, number of flowers and seed yield, and that this phenotype is lost when plants are grown in low $\mathrm{N}$ condition.

Engineered plants that express SyNOS unlike the expression of other NOS would remobilize $\mathrm{N}$ stored in Arg internal pools

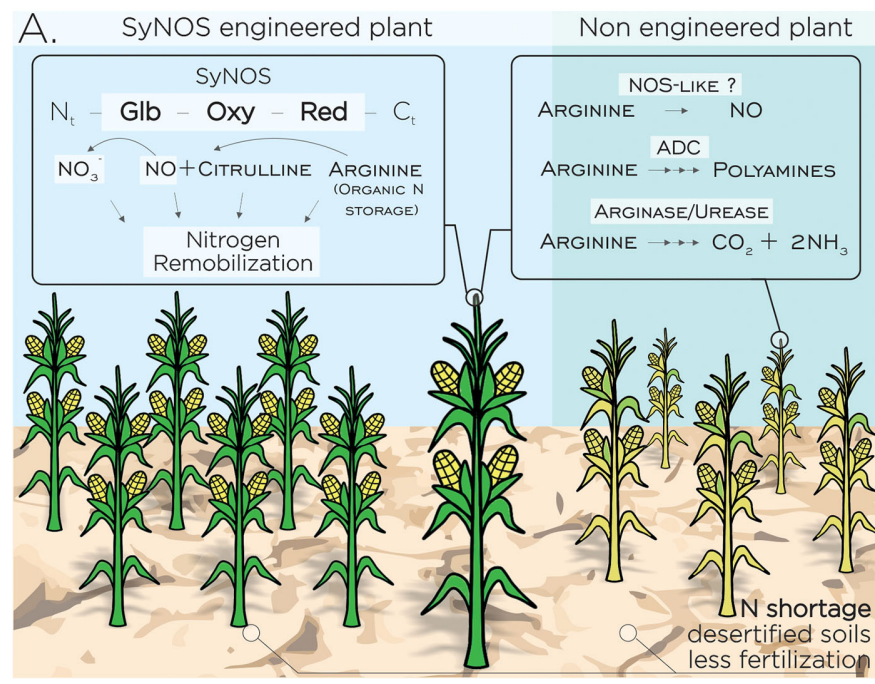

B.

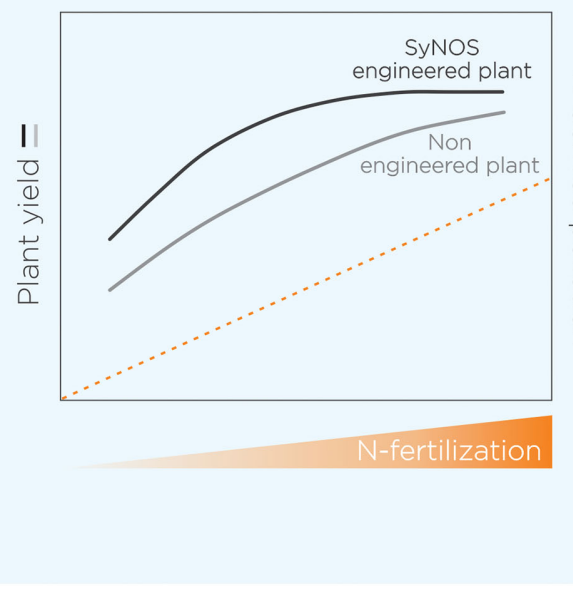

FIGURE 1 | Plant N remobilization as a target of biotechnological strategy to promote lower fertilization and N pollution in a climate change context. (A) Increased N remobilization from plant reservoirs through heterologous and/or overexpression of specific enzymes could enhance growth and yield of crops to cope with desertified soils. Plants tolerant to N scarcity will also help to reduce the use of fertilizers and their impact on the environment. We postulate the heterologous expression of NOS from Synechococcus PCC 7335 (SyNOS) in plants as a biotechnological tool to increase N remobilization. SyNOS contains a singular globin (Glb) domain at the 5'-end, followed by the canonical oxygenase (Oxy) and reductase (Red) domains of NOS enzymes. SyNOS activity may remobilize N from Arg internal pools in plants leading to $\mathrm{NO}$ and $\mathrm{NO}_{3}{ }^{-}$formation, the last contributes to improve plant NUE. SyNOS would be a gain of function increasing the number of Arg-metabolizing enzymes in plant cells: arginase, Arg decarboxylase (ADC) and NOS-like activity. (B) Postulated scenario showing non-engineered plant yield (adapted from Brueck and Lammel, 2016) and putative yield of SyNOS-engineered plants, in variable levels of N fertilization and environmental pollution. Dashed lines show positive correlation between environmental pollution and $\mathrm{N}$ fertilization (Zhang et al., 2019). 
producing $\mathrm{NO} / \mathrm{NO}_{3}{ }^{-}$and may be an interesting tool to improve $\mathrm{N}$ metabolism (Figure 1). Although plants have Arg degrading enzymes (i.e., arginase), the incorporation of Arg catabolic pathways in crops may improve $\mathrm{N}$ remobilization and plant productivity. It was reported that the overexpression of arginases improves NUE and seed yield in rice and cotton under different $\mathrm{N}$ conditions (Ma et al., 2013; Meng et al., 2015). These results support our hypothesis and suggest that SyNOS expression would be an alternative strategy that generates other $\mathrm{N}$ sources $\left(\mathrm{NO}_{3}{ }^{-} /\right.$ NO) and may favor crop productivity. NO produced by SyNOS might also cope to stress tolerance (Del Castello et al., 2019; Kolbert et al., 2019). Despite this, unexpected phenotypes concerning changes in NO homeostasis should be analyzed, as well as the consequences of potential changes in Arg concentration as substrate of different metabolic pathways (i.e., polyamine synthesis). In addition, genetic variations among cultivars, time of harvest (vegetative/reproductive phase), crop management should be considered when defining a strategy for NUE improvement.

Overall, the discovery of novel enzymes involved in NUE in photosynthetic organisms will facilitate transferring our knowledge from theory to practice and generate crops to boost agriculture when confronting serious environmental challenges.

\section{REFERENCES}

Alderton, W. K., Cooper, C. E., and Knowles, R. G. (2001). Nitric oxide synthases: structure, function and inhibition. Biochem. J. 357, 593-615. doi: 10.1042/ bj3570593

Bennett, J. A., and Klironomos, J. (2019). Mechanisms of plant-soil feedback: interactions among biotic and abiotic drivers. New Phytol. 222, 91-96. doi: $10.1111 /$ nph.15603

Bertoni, G. (2017). An emerging model diatom to study nitrogen metabolism. Plant Cell 29, 1795-1796. doi: 10.1105/tpc.17.00651

Breitburg, D., Levin, L. A., Oschlies, A., Grégoire, M., Chavez, F. P., Conley, D. J., et al. (2018). Declining oxygen in the global ocean and coastal waters. Sci. (80-.). 359, eaam7240. doi: 10.1126/science.aam7240

Brueck, H., and Lammel, J. (2016). Impact of Fertilizer N Application on the Grey Water Footprint of Winter Wheat in a NW-European Temperate Climate. Water 8:356. doi: 10.3390/w8080356

Burnat, M., Picossi, S., Valladares, A., Herrero, A., and Flores, E. (2019). Catabolic pathway of arginine in Anabaena involves a novel bifunctional enzyme that produces proline from arginine. Mol. Microbiol. 111, 883-897. doi: 10.1111/ mmi.14203

Cai, W., Liu, W., Wang, W.-S., Fu, Z.-W., Han, T.-T., and Lu, Y.-T. (2015). Overexpression of Rat Neurons Nitric Oxide Synthase in Rice Enhances Drought and Salt Tolerance. PloS One 10, e0131599. doi: 10.1371/journal.pone.0131599

Chamizo-Ampudia, A., Sanz-Luque, E., Llamas, Á., Ocaña-Calahorro, F., Mariscal, V., Carreras, A., et al. (2016). A dual system formed by the ARC and NR molybdoenzymes mediates nitrite-dependent NO production in Chlamydomonas. Plant Cell Environ. 39, 2097-2107. doi: 10.1111/pce.12739

Chen, Q., Soulay, F., Saudemont, B., Elmayan, T., Marmagne, A., and MasclauxDaubresse, C. (2019). Overexpression of ATG8 in Arabidopsis Stimulates Autophagic Activity and Increases Nitrogen Remobilization Efficiency and Grain Filling. Plant Cell Physiol. 60, 343-352. doi: 10.1093/pcp/pcy214

Chun, H. J., Park, H. C., Koo, S. C., Lee, J. H., Park, C. Y., Choi, M. S., et al. (2012). Constitutive expression of mammalian nitric oxide synthase in tobacco plants triggers disease resistance to pathogens. Mol. Cells 34, 463-471. doi: 10.1007/ s10059-012-0213-0

Conley, D. J., Paerl, H. W., Howarth, R. W., Boesch, D. F., Seitzinger, S. P., Havens, K. E., et al. (2009). Controlling Eutrophication: Nitrogen and Phosphorus. Sci. (80-. ). 323, 1014-1015. doi: 10.1126/science.1167755

\section{AUTHOR CONTRIBUTIONS}

FC and AN contributed equally to this Hwork. All authors contributed to the article and approved the submitted version.

\section{FUNDING}

This research was supported by the Agencia Nacional de Promoción Científica y Tecnológica (ANPCyT: PICTs 2927/ 2015 to LL and PICT 2524/2018 to NC-A.), the Consejo Nacional de Investigaciones Científicas y Técnicas (CONICET, PIP 0646/2015 to NC-A) and institutional grants from the Universidad Nacional de Mar del Plata (UNMdP), Argentina.

\section{ACKNOWLEDGMENTS}

We acknowledge Mar del Plata University and the Consejo Nacional de Investigaciones Científicas y Técnicas (CONICET). We thank Clara Farro for the figure design. FC and $\mathrm{AN}$ are $\mathrm{PhD}$ fellows and NF, LL, and NC-A are members of the research staff from CONICET, Argentina.

Corpas, F. J., and Barroso, J. B. (2017). Nitric oxide synthase-like activity in higher plants. Nitric. Oxide - Biol. Chem. 68, 5-6. doi: 10.1016/j.niox.2016.10.009

Correa-Aragunde, N., Foresi, N., Del Castello, F., and Lamattina, L. (2018). A singular nitric oxide synthase with a globin domain found in Synechococcus PCC 7335 mobilizes N from arginine to nitrate. Sci. Rep. 8, 1-11. doi: 10.1038/ s41598-018-30889-6

Coruzzi, G. M., and Zhou, L. (2001). Carbon and nitrogen sensing and signaling in plants : emerging 'matrix effects'. Curr. Opin. Plant Biol. 4, 247-253. doi: 10.1016/S1369-5266(00)00168-0

Crane, B. R., Sudhamsu, J., and Patel, B. A. (2010). Bacterial nitric oxide synthases. Annu. Rev. Biochem. 79, 445-470. doi: 10.1146/annurev-biochem-062608103436

Del Castello, F., Nejamkin, A., Cassia, R., Correa-Aragunde, N., Fernández, B., Foresi, N., et al. (2019). The era of nitric oxide in plant biology: Twenty years tying up loose ends. Nitric. Oxide 85, 17-27. doi: 10.1016/J.NIOX.2019.01.013

Di Dato, V., Musacchia, F., Petrosino, G., Patil, S., Montresor, M., Sanges, R., et al. (2015). Transcriptome sequencing of three Pseudo-nitzschia species reveals comparable gene sets and the presence of Nitric Oxide Synthase genes in diatoms. Sci. Rep. 5, 12329. doi: 10.1038/srep12329

Djennane, S., Chauvin, J. E., and Meyer, C. (2002). Glasshouse behaviour of eight transgenic potato clones with a modified nitrate reductase expression under two fertilization regimes. J. Exp. Bot. 53, 1037-1045. doi: 10.1093/jexbot/ 53.371.1037

Ferrario-Méry, S., Valadier, M. H., and Foyer, C. H. (1998). Overexpression of nitrate reductase in tobacco delays drought-induced decreases in nitrate reductase activity and mRNA. Plant Physiol. 117, 293-302. doi: 10.1104/ pp.117.1.293

Flynn, K. J. (1991). Algal carbon-nitrogen metabolism: A biochemical basis for modelling the interactions between nitrate and ammonium uptake. J. Plankton Res. 13, 373-387. doi: 10.1093/plankt/13.2.373

Foresi, N., Correa-Aragunde, N., Parisi, G., Calo, G., Salerno, G., and Lamattina, L. (2010). Characterization of a nitric oxide synthase from the plant kingdom: NO generation from the green alga Ostreococcus tauri is light irradiance and growth phase dependent. Plant Cell 22, 3816-3830. doi: 10.1105/ tpc.109.073510

Foresi, N., Mayta, M. L., Lodeyro, A. F., Scuffi, D., Correa-Aragunde, N., GarcíaMata, C., et al. (2015). Expression of the tetrahydrofolate-dependent nitric oxide synthase from the green alga Ostreococcus tauri increases tolerance to 
abiotic stresses and influences stomatal development in Arabidopsis. Plant J. 82, 806-821. doi: $10.1111 /$ tpj.12852

Foresi, N., Correa-Aragunde, N., and Lamattina, L. (2017). "Synthesis, Actions, and Perspectives of Nitric Oxide in Photosynthetic Organisms," in Nitric Oxide. Eds. L. J. Ignarro and B. A. Freeman (London, UK: Elsevier), 125-136. doi: 10.1016/B978-0-12-804273-1.00010-7

Fuller, R. C., and Nugent, N. A. (1969). Pteridines and the function of the photosynthetic reaction center. Proc. Natl. Acad. Sci. U. S. A. 63, 1311-1318. doi: 10.1073/pnas.63.4.1311

Gaufichon, L., Marmagne, A., Belcram, K., Yoneyama, T., Sakakibara, Y., Hase, T., et al. (2017). ASN1 -encoded asparagine synthetase in floral organs contributes to nitrogen filling in Arabidopsis seeds. Plant J. 91, 371-393. doi: 10.1111/ tpj.13567

Good, A. G., Johnson, S. J., De Pauw, M., Carroll, R. T., Savidov, N., Vidmar, J., et al. (2007). Engineering nitrogen use efficiency with alanine aminotransferase. Can. J. Bot. 85, 252-262. doi: 10.1139/B07-019

Griffith, O. W., and Stuehr, D. J. (1995). Nitric Oxide Synthases: Properties and Catalytic Mechanism. Annu. Rev. Physiol. 57, 707-734. doi: 10.1146/ annurev.ph.57.030195.003423

Havens, K., Paerl, H., Phlips, E., Zhu, M., Beaver, J., and Srifa, A. (2016). Extreme weather events and climate variability provide a lens to how shallow lakes may respond to climate change. Water (Switzerland) 8, 1-18. doi: 10.3390/ w8060229

Hoegh-Guldberg, O., Jacob, D., Bindi, M., Brown, S., Camilloni, I., Diedhiou, A., et al. (2018). Impacts of $1.5 \mathrm{C}$ global warming on natural and human systems. Glob. Warm. $1.5^{\circ} \mathrm{C}$ (Switzerland: An IPCC Spec. Rep).

Jeandroz, S., Wipf, D., Stuehr, D. J., Lamattina, L., Melkonian, M., Tian, Z., et al. (2016). Occurrence, structure, and evolution of nitric oxide synthase-like proteins in the plant kingdom. Sci. Signal. 9, re2-re2. doi: 10.1126/ scisignal.aad4403

Kinkel, T. L., Ramos-Montañez, S., Pando, J. M., Tadeo, D. V., Strom, E. N., Libby, S. J., et al. (2016). An essential role for bacterial nitric oxide synthase in Staphylococcus aureus electron transfer and colonization. Nat. Microbiol. 2, 16224. doi: 10.1038/nmicrobiol.2016.224

Kolbert, Z., Feigl, G., Freschi, L., and Poór, P. (2019). Gasotransmitters in Action: Nitric Oxide-Ethylene Crosstalk during Plant Growth and Abiotic Stress Responses. Antioxidants 8, 167. doi: 10.3390/antiox8060167

Kumar, A., Castellano, I., Patti, F. P., Palumbo, A., and Buia, M. C. (2015). Nitric oxide in marine photosynthetic organisms. Nitric. Oxide 47, 34-39. doi: 10.1016/j.niox.2015.03.001

Li, H., Hu, B., and Chu, C. (2017). Nitrogen use efficiency in crops: lessons from Arabidopsis and rice. J. Exp. Bot. 68, 2477-2488. doi: 10.1093/jxb/erx101

Llamas, A., Chamizo-Ampudia, A., Tejada-Jimenez, M., Galvan, A., and Fernandez, E. (2017). The molybdenum cofactor enzyme mARC: Moonlighting or promiscuous enzyme? BioFactors 43, 486-494. doi: 10.1002/biof.1362

Ma, X., Cheng, Z., Qin, R., Qiu, Y., Heng, Y., Yang, H., et al. (2013). OsARG encodes an arginase that plays critical roles in panicle development and grain production in rice. Plant J. 73, 190-200. doi: 10.1111/j.1365-313x.2012.05122.x

Meng, Z., Meng, Z., Zhang, R., Liang, C., Wan, J., Wang, Y., et al. (2015). Expression of the rice arginase gene OsARG in cotton influences the morphology and nitrogen transition of seedlings. PloS One 10, 1-19. doi: 10.1371/journal.pone. 0141530

Nadelhoffer, K. J., Emmett, B. A., Gundersen, P., Kjønaas, O. J., Koopmans, C. J., Schleppi, P., et al. (1999). Nitrogen deposition makes a minor contribution to carbon sequestration in temperate forests. Nature 398, 145-148. doi: 10.1038/18205

Nejamkin, A., Foresi, N., Mayta, M. L., Lodeyro, A. F., Castello, F., CorreaAragunde, N., et al. (2020). Nitrogen Depletion Blocks Growth Stimulation Driven by the Expression of Nitric Oxide Synthase in Tobacco. Front. Plant Sci. 11, 312. doi: $10.3389 /$ fpls.2020.00312

Oliveira, I. C., Brears, T., Knight, T. J., Clark, A., and Coruzzi, G. M. (2002). Overexpression of cytosolic glutamine synthetase. Relation to nitrogen, light, and photorespiration. Plant Physiol. 129, 1170-1180. doi: 10.1104/pp.020013

Olsson, L., Barbosa, H., Bhadwal, S., Cowie, A., Delusca, K., Flores-Renteria, D., et al. (2019). "Land degradation," in Climate Change and Land: an IPCC special report on climate change, desertification, land degradation, sustainable land management, food security, and greenhouse gas fluxes in terrestrial ecosystems
(Cambridge, UK: Cambridge University Press), 345-436. doi: 10.1017/ CBO9780511622991.009

Perchlik, M., and Tegeder, M. (2017). Improving plant nitrogen use efficiency through alteration of amino acid transport processes. Plant Physiol. 175, 235247. doi: $10.1104 /$ pp. 17.00608

Picciano, A. L., and Crane, B. R. (2019). A nitric oxide synthase-like protein from Synechococcus produces $\mathrm{NO} / \mathrm{NO}_{3}{ }^{-}$from 1 -arginine and $\mathrm{NAPDH}$ in a tetrahydrobiopterin- and $\mathrm{Ca}^{2+}$-dependent manner. J. Biol. Chem. 294, 10708-10719. doi: 10.1074/jbc.RA119.008399

Poole, R. K., and Hughes, M. N. (2000). New functions for the ancient globin family: Bacterial responses to nitric oxide and nitrosative stress. Mol. Microbiol. 36, 775-783. doi: 10.1046/j.1365-2958.2000.01889.x

Presta, A., Siddhanta, U., Wu, C., Sennequier, N., Huang, L., Abu-Soud, H. M., et al. (1998). Comparative functioning of dihydro- and tetrahydropterins in supporting electron transfer, catalysis, and subunit dimerization in inducible nitric oxide synthase. Biochemistry 37, 298-310. doi: 10.1021/ bi971944c

Pugnaire, F.II, Morillo, J. A., Peñuelas, J., Reich, P. B., Bardgett, R. D., Gaxiola, A., et al. (2019). Climate change effects on plant-soil feedbacks and consequences for biodiversity and functioning of terrestrial ecosystems. Sci. Adv. 5, 1-11. doi: 10.1126/sciadv.aaz1834

Rodríguez-Ruiz, M., Zuccarelli, R., Palma, J. M., Corpas, F. J., and Freschi, L. (2019). "Biotechnological Application of Nitric Oxide and Hydrogen Peroxide in Plants," in Nitric Oxide and Hydrogen Peroxide Signaling in Higher Plants (Switzerland: Springer International Publishing), 245-270. doi: 10.1007/978-3030-11129-8_12

Sahr, T., Ravanel, S., and Rébeillé, F. (2005). Tetrahydrofolate biosynthesis and distribution in higher plants. Biochem. Soc Trans. 33, 758-762. doi: 10.1042/ BST0330758

Sanz-Luque, E., Ocaña-Calahorro, F., De Montaigu, A., Chamizo-Ampudia, A., Llamas, Á., Galván, A., et al. (2015). THB1, a truncated hemoglobin, modulates nitric oxide levels and nitrate reductase activity. Plant J. 81, 467-479. doi: $10.1111 /$ tpj.12744

Schlesinger, W. H. (2009). On the fate of anthropogenic nitrogen. Proc. Natl. Acad. Sci. U. S. A. 106, 203-208. doi: 10.1073/pnas.0810193105

Seregélyes, C., and Dudits, D. (2003). Phytoglobins and nitric oxide: New partners in an old signalling system in plants. Acta Biol. Hung. 54, 15-25. doi: 10.1556/ ABiol.54.2003.1.2

Shang, Z. H., Feng, Q. S., Wu, G. L., Ren, G. H., and Long, R. J. (2013). Grasslandification has significant impacts on soil carbon, nitrogen and phosphorus of alpine wetlands on the Tibetan Plateau. Ecol. Eng. 58, 170179. doi: 10.1016/j.ecoleng.2013.06.035

Shi, H.-T., Li, R.-J., Cai, W., Liu, W., Wang, C.-L., and Lu, Y.-T. (2012). Increasing nitric oxide content in Arabidopsis thaliana by expressing rat neuronal nitric oxide synthase resulted in enhanced stress tolerance. Plant Cell Physiol. 53, 344-357. doi: 10.1093/pcp/pcr181

Shi, H., Ye, T., Zhu, J.-K., and Chan, Z. (2014). Constitutive production of nitric oxide leads to enhanced drought stress resistance and extensive transcriptional reprogramming in Arabidopsis. J. Exp. Bot. 65, 4119-4131. doi: 10.1093/jxb/ eru184

Shrawat, A. K., Carroll, R. T., DePauw, M., Taylor, G. J., and Good, A. G. (2008). Genetic engineering of improved nitrogen use efficiency in rice by the tissuespecific expression of alanine aminotransferase. Plant Biotechnol. J. 6, 722-732. doi: $10.1111 / j .1467-7652.2008 .00351 . x$

Smith, S. R., Dupont, C. L., McCarthy, J. K., Broddrick, J. T., Oborník, M., Horák, A., et al. (2019). Evolution and regulation of nitrogen flux through compartmentalized metabolic networks in a marine diatom. Nat. Commun. 10, 4552. doi: 10.1038/s41467-019-12407-y

Straub, A. C., Lohman, A. W., Billaud, M., Johnstone, S. R., Dwyer, S. T., Lee, M. Y., et al. (2012). Endothelial cell expression of haemoglobin $\alpha$ regulates nitric oxide signalling. Nature 491, 473-477. doi: 10.1038/nature11626

Tang, Z.-S., An, H., and Shangguan, Z.-P. (2015). The impact of desertification on carbon and nitrogen storage in the desert steppe ecosystem. Ecol. Eng. 84, 9299. doi: 10.1016/j.ecoleng.2015.07.023

Tejero, J., and Gladwin, M. T. (2014). The globin superfamily: Functions in nitric oxide formation and decay. Biol. Chem. 395, 631-639. doi: 10.1515/hsz-20130289 
Tharammal, T., Bala, G., Narayanappa, D., and Nemani, R. (2019). Potential roles of $\mathrm{CO}_{2}$ fertilization, nitrogen deposition, climate change, and land use and land cover change on the global terrestrial carbon uptake in the twenty-first century. Clim. Dyn. 52, 4393-4406. doi: 10.1007/s00382-018-4388-8

Vinogradov, S. N., and Moens, L. (2008). Diversity of globin function: Enzymatic, transport, storage, and sensing. J. Biol. Chem. 283, 8773-8777. doi: 10.1074/ jbc.R700029200

Wilkinson, J. Q., and Crawford, N. M. (1991). ldentification of the Arabidopsis CHL3 Gene as the Nitrate Reductase Structural Gene MA2. Plant Cell 3, 461-471. doi: 10.1105/tpc.3.5.461

Winter, G., Todd, C. D., Trovato, M., Forlani, G., and Funck, D. (2015). Physiological implications of arginine metabolism in plants. Front. Plant Sci. 6:534. doi: 10.3389/fpls.2015.00534

Zhang, H., Liu, Y., Nie, X., Liu, L., Hua, Q., Zhao, G., et al. (2018). The cyanobacterial ornithine-ammonia cycle involves an arginine dihydrolase. Nat. Chem. Biol. 14, 575-581. doi: 10.1038/s41589-018-0038-z
Zhang, C., Ju, X., Powlson, D., Oenema, O., and Smith, P. (2019). Nitrogen Surplus Benchmarks for Controlling N Pollution in the Main Cropping Systems of China. Environ. Sci. Technol. 53, 6678-6687. doi: 10.1021/ acs.est. 8 b06383

Conflict of Interest: The authors declare that the research was conducted in the absence of any commercial or financial relationships that could be construed as a potential conflict of interest.

Copyright (C) 2020 Del Castello, Nejamkin, Foresi, Lamattina and Correa-Aragunde. This is an open-access article distributed under the terms of the Creative Commons Attribution License (CC BY). The use, distribution or reproduction in other forums is permitted, provided the original author(s) and the copyright owner(s) are credited and that the original publication in this journal is cited, in accordance with accepted academic practice. No use, distribution or reproduction is permitted which does not comply with these terms. 